\title{
Anmeldelse: Stalins krig mod Ukraine
}

Læst parallelt giver Anne Appelbaum og Bent Jensens bøger et særdeles dækkende billede af udviklingen og situationen i den tidlige fase af sovjetstyret, og Hergé bidrager på sin egen uakademiske, men indsigtsfulde måde også til at forstå styret.

Anne Appelbaum: Rød sult. Stalins hungersnød i Ukraine, Kristeligt Dagblads Forlag, 2018.

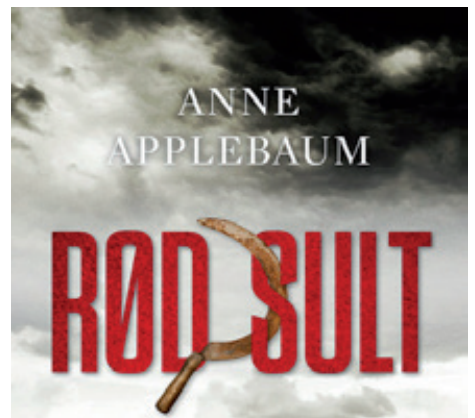

STALINS HUNGERSNØD I UKRAINE

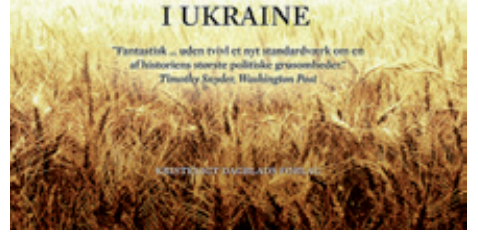

Ruslands undergang, Revolutioner og sammenbrud,

Gyldendals Forlag, 2017.

Hergé: Tintin i Sovjetunionen, 5. kolorerede udg., Forlaget Cobolt, 2017. Faraos Cigarer.

Anne Appelbaum hører til de førende både populære og videnskabelige forfattere inden for litteraturen om

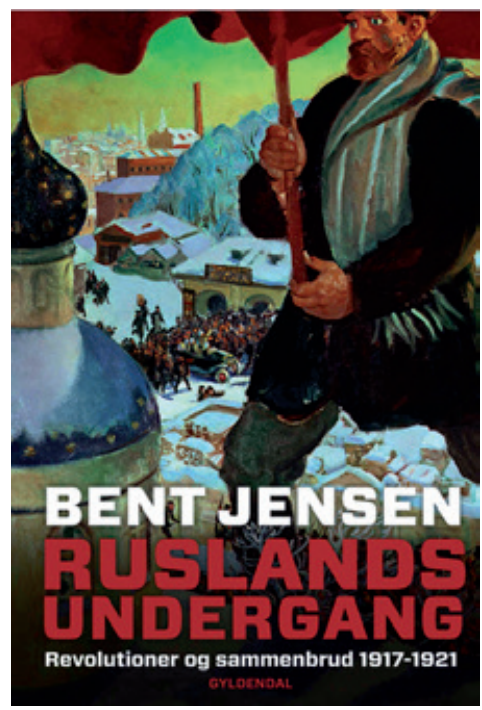

Jan Jakob Floryan er cand.scient.pol. \& art. 
Sovjetunionen og den sovjetsocialistiske totalitarisme. Hun er kommentator for The Washington Post, professor ved London School of Economics og modtager af Pulitzer Prisen. Hun er amerikaner, men bor i dag i Warszawa, hvor hun er gift med den polske politiker Radosław Sikorski. Hun har en dyb viden om sovjetregimet og formidler den på forbilledligt vis, senest i bogen om sultedøden i Ukraine, hvis engelske undertitel måske er mere dækkende end den danske: Stalin's War on Ukraine.

Det var nemlig krig, den sovjetiske diktator førte mod den ukrainske sovjetrepubliks bønder. Det skete i flere tempi og med tiltagende brutalitet og nådesløshed. Våbenet var kun i mindre grad geværer og henrettelser. Døden i millionvis overlod Stalin til sulten. Det oprindelige, ideologisk korrekte dække var kampen for kollektiviseringen. Ukraines frugtbare jorder og navnlig sortjordsområdet var Ruslands og verdens brødkurv. Ukraine var i Det Russiske Imperiums tid en af de vigtigste kornproducenter på linje med Argentina og USA. Det gjorde flertallet af ukrainske bønder velhavende.

\section{Livegenskabet}

Mens Appelbaum fokuserer på sultedødens politiske årsager og dens morderiske konsekvenser, leverer Bent Jensen viden og indsigt i de russiske bønders historie fra livegenskabets ophævelse og til indførelsen af det nye, socialistiske livegenskab i 1930'erne. Af Mikhail Gorbatjov betegnet som 'det andet livegnskab'.
I zartiden var de russiske bønder både fæstebønder og underlagt hoveri, men i 1861 introducerede zar Aleksander den II en forsigtig landboreform. Bønderne blev juridiske personer og fik mulighed for at købe deres lodder af herremændene. Der kom et vist skred i bøndernes erhvervelse af jord, da godsejerne begyndte at sælge ud i anden halvdel af det 19 . århundrede.

Deres liv blev dog stadig i hovedsagen bestemt af landsbyens mir, der betegner en rådsforsamling (ordet betyder også verden og fred). Miren traf afgørelse om fordelingen af jordene mellem landsbyens familier, og der fandt justeringer sted, alt efter hvor mange munde, der nu var at mætte i den pågældende husstand. Det gjorde, skriver Bent Jensen, at bønderne ikke kunne opfatte de anviste lodder som deres og ingen interesse havde i forbedringer, for det kunne jo nemt ske, at de skulle afgive dem ved næste regulering.

Miren var imidlertid landsbylivets omdrejningspunkt og vigtigste instans, idet den også stod for alt det ubehagelige for bønderne: skat og rekruttering af soldater. Hvad bolsjevikkernes konsekvente ødelæggelse af miren som et selvstyreorgan i praksis betød for de ukrainske bønder, står klart og tydeligt frem i Appelbaums bog: deres faste holdepunkt forsvandt og blev erstattet af kollektivbrug og deres indsatte bestyrere.

Efter revolutionen i februar 1917 stilede den provisoriske regering mod en landboreform, men den skulle gennemføres på ordentlig vis med erstat- 
ning til jordejerne finansieret af statslige lån til bønderne. Bolsjevikkerne, mensjevikkerne, anarkisterne og andre revolutionære havde imidlertid en anden idé. Et af deres vigtigste virkemidler til at undergrave regeringen og krigsindsatsen var det simple opråb til soldaterne dvs. bønderne om at forlade hæren, tage hjem til landsbyerne og tage jorden i besiddelse; og skulle herremændene omkomme i den forbindelse, gjorde det intet, for de var klassefjender. Det bolsjevikiske kup i november 1917 banede vejen for denne 'reform'.

Der fulgte nogle vilde år med selvtægt og kaos. Bent Jensen citerer flere russiske forfattere og samtidige samfundsforskere, der giver en alt andet end flatterende beskrivelse af de russiske bønder som voldelige, brutale, hævngerrige, aggressive og i øvrigt analfabeter. Hvordan de kunne myrde herremændene og deres sønner samt voldtage de adelige kvinder til døde for derefter at gå i kirke og gøre afbigt for deres ugerninger?

\section{Kollektivisering og sultedød}

I det gamle Rusland blev bønderne holdt $\mathrm{i}$ ave med knut, den nihalede, og i hæren med kadaverdisciplin. Det hindrede ikke adskillige bondeoprør i at bryde ud, og her var det kosakkerne og feltartilleriet, der rykkede ud. Det var disse bøndernes laveste instinkter, bolsjevikkernes appellerede til og lod udfolde sig uhæmmet, skriver Appelbaum. Det var imidlertid kun et blodigt skalkeskjul. Alt som bønderne troede, at nu havde de endelig fået fat $\mathrm{i}$ godsejernes jord, satte bolsjevikkerne ind med den næste velovervejede fase: kollektiviseringen.

Hvordan den gik for sig, beskrives detaljeret og hårrejsende præcist af Appelbaum. Læsningen af hendes og Bent Jensens bøger parallelt giver et særdeles dækkende billede af udviklingen og situationen i den tidlige fase af sovjetstyret. Her ønsker jeg også af nævne Hergé. Den belgiske tegneserieforfatter lancerede i 1929 sit første album om den utroligt snarrådige og nysgerrige journalist Tintin og hans følgesvend terrieren Terry. I albummet om Tintin i Sovjetunionen formår tegneren Hergé, der ikke havde nogen baggrund i historie eller politologi, at fremhæve og illustrere med en tegneseries simple, men stærke virkemidler alt det, som en stor del af de vestlige intellektuelle ikke kunne eller ville se: terroren.

Det her bragte billede er en eminent illustration af Appelbaums skildring af de ungkommunistiske brigaders og Den Røde Hærs nådesløse jagt på det sidste korn og den sidste krumme blandt de ukrainske bønder, som derefter blev overladt til sulten. Det skal tilføjes, at samme skæbne overgik andre frugtbare og kornproducerende områder som kosakkernes Kuban, Krim, Nedre Volga og Kazakhstan.

Appelbaum angiver antallet af ofre ved hungersnøden 1932-33 i Ukraine til 3,9 mio., heraf 400.000 i byerne. I Schwarzbuch des Kommunismus (red. Stéphan Courtois) sættes tallet til fire mio., mens Robert Conquest i standardværket The Great Terror skønner tallet af sultedødens ofre for Sovjetunionen som helhed til cir- 


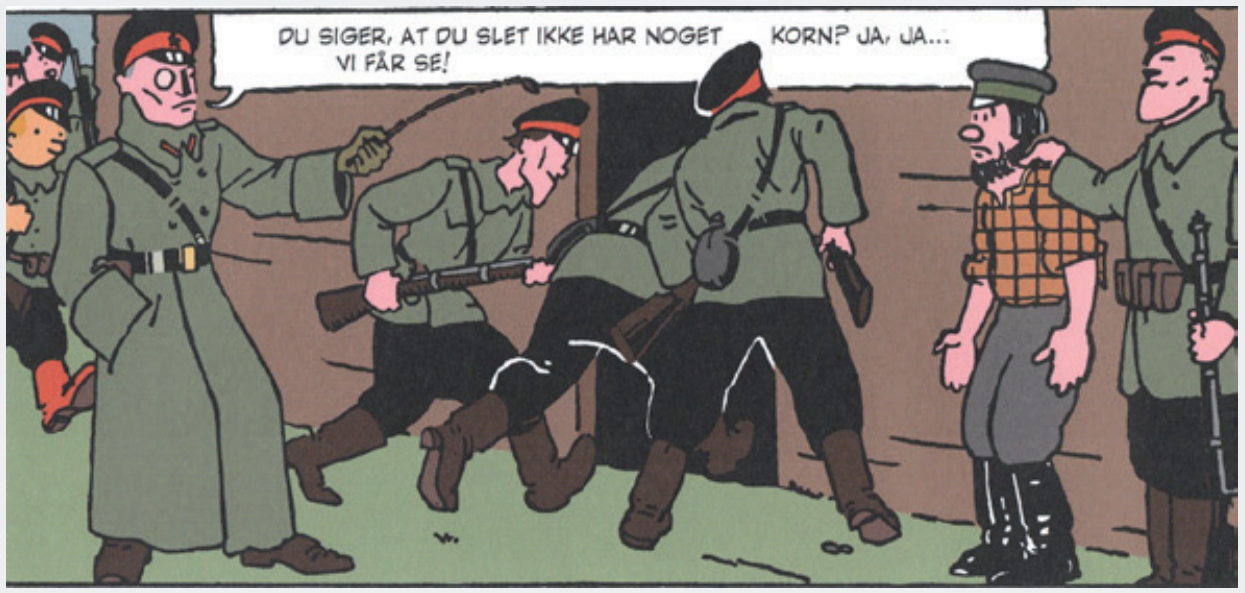

ILL.: Forlaget Cobolt 2018; anmeldereksemplar Faraos Cigarer

ka 20 mio. Folketællingerne for 1937 og 1939 blev holdt hemmelige til op i perestrojka-tiden.

Fascinerende er Appelbaums fremstilling af de politiske forberedelser til sultedøden, der blev lanceret i to tempi. En generalprøve blev afholdt i 1929, hvor kollektiverne i Ukraine blev pålagt urealistiske krav om kornleverancer, hvorefter udsendte brigader beslaglagde al korn, de kunne finde. Andre fødemidler og koen, grisen og hønsene fik bønderne dog lov til at beholde.

Men den 14. og 15. december 1932 blev afgørende beslutninger truffet i Kreml under forsæde af Stalin. Forklaringen var, at den ukrainisering af sovjetrepublikken, man havde tilladt, havde vist sig at fostre nationalistiske og antisovjetiske bevægelser. Derfor skulle der slås til i Ukraine, som Stalin i øvrigt var fjendtligt indstillet overfor på grund af ukrainernes forsøg på at opnå selvstændighed efter imperiets opløsning og deres alliance med Polen.

Som Stalins særlige og befuldmægtige udsending kom politbureaumedlemmet Lazar Kaganovitj til landet. Hans opgave bestod i dels at sørge for de strengeste ordres inappelable gennemførelse, dels luge ud i det ukrainske kommunistparti, som Stalin anså for ikke at være tilstrækkeligt pålideligt. Kaganovitj og sikkerhedstjenesten OGPU's chef i Ukraine, Vsevold Balytskij, gik herefter i gang med udrensninger samt forberedelse af sultedøden, på ukrainsk Holodomor (Holod - sult; mor - død).

Der kan undre, at Appelbaum, der er af jødisk herkomst, ikke her så meget som nævner et andet veltilrettelagt folkemord: Endlösing af det jødiske spørgsmål i Europa. Også her skred processen frem med en række forløbere, der omfattede arrestationer og 
tilintetgørelse af jøder i de besatte områder, men uden at være sat i system og forvandlet til en industriel proces.

Som med Holodomor, hvor de afgørende beslutninger kan føres tilbage til december 1932, kan Endlösungs genese spores til den skelsættende Wannsee-konference den 20. januar 1942. Konferencen var en følge af rigsmarskal Görings ordre til Reinhard Heydrich om at tilrettelægge og iværksætte tilintetgørelsesprogrammet. Hans vigtigste assistent var Adolf Eichmann.

Det gik de sovjetsocialistiske og nationalsocialistiske forbrydere meget forskelligt. Vsevold Balytskij blev anholdt i 1947 og skudt som led i en af Stalins udrensninger. Kaganovitj gik fri og døde i 1991 kort tid før Sovjetunionens sammenbrud. Blandt tyskerne begik Göring selvmord, Heydrich blev dræbt af tjekkoslovakiske modstandsfolk, mens Eichmann blev bortført af israelske Mossad og dømt til døden. Således er han den eneste, der kan siges at have fået en berettiget straf.

Det er et af de mest spændende elementer i Appelbaums bog at følge med i den bureaukratiske proces, der skridt for skridt og under overholdelse af sine egne formalistiske regler bevægede sig i retning af folkemordet på de ukrainske bønder.

\section{Løgnen og propagandaen}

En anden tråd i beretningen om Holdomor er beskrivelsen af propagandaen og løgnen, der omgærdede den. Censuren sørgede for, at intet trængte ud og eliminerede selv de vageste hen- tydninger. Samtidig blev den evidente mangel på korn forklaret med en intensivering af den kontrarevolutionære klassekamp fra kulakkernes side. Det blev heller ikke nævnt, at selv i perioden med den mest udtalte mangel på korn, opretholdt Sovjetunionen en vis eksport for at tjene den hårdt tiltrængte fremmedvaluta.

Under sultedøden blev de ukrainske landdistrikter, dvs. hovedparten af landet, afskåret fra omverdenen. Det var ikke muligt at komme ind eller ud. Jernbanestationerne var bevogtet, så de sultende ikke kunne stige ombord på tog, vejene ud af republikken var spærret, og det var indkørslerne til byerne også, for her var der mad til arbejderne. Men bevares, indbyggerne i den bayerske landsby Dachau vidste heller ikke, hvad der foregik nogle kilometer derfra i koncentrationslejren af samme navn.

Appelbaums fremstilling er bygget op på dels de historiske analyser, dels et utal af skriftlige og mundtlige øjenvidneberetninger eller overleverede fortællinger i familierne. Her ligner den meget Oxford-professoren Orlando Figes' storværk Hviskerne om tavshedens kultur i Sovjetunionen.

På det felt adskiller Bent Jensens bog sig markant fra de to nævnte værker. Her er der tale om et gedigent, traditionelt historisk værk, hvor citater kun stammer fra fremtrædende personer inden for politik eller samfundsvidenskab. Det får én til at overveje, hvilken tilgang mon er den bedste?

Hvis man skal kritisere de mange ofte meget korte citater, som Appel- 
baum (og Figes) indføjer i teksten, vil det være, at de afbryder den længere og sammenhængende præsentation, og man skal så at sige hoppe fra citat til citat for at fastholde den overordnede tanke. Omvendt virker Bent Jensens tekst lidt klinisk og uden det medlevende engagement, som citaterne bidrager med.

Disse stilistiske forskelle er dog underordnede, idet begge værker varmt må anbefales som markante nedslag $\mathrm{i}$ udforskningen af det sovjetsocialistiske regime. Og glem ikke Hergé, der på sin egen uakademiske, men indsigtsfulde måde også bidrager til forståelse af styret.
Til sidst en tilskyndelse til, hvis man skulle komme til Kiev, at opsøge $\mathrm{Ho}$ lodomor-museet. Frem til Sovjetunionens sammenbrud var enhver tale om folkemordet forbudt, om end systemet begyndte at sprække i de sidste par år under Gorbatjov. I det uafhængige Ukraine har Holodomor fåt en fortjent plads som den største tragedie i det ukrainske folks historie og er blevet sidestillet med det armenske folkemord og med Holocaust.

000 